Algirdas Gricius*

Institute of International Relations and Political Science of the University of Vilnius

Kestutis Paulauskas"

Institute of International Relations and Political Science of the University of Vilnius

\title{
Democratic Control over the Armed Forces in Lithuania
}

The concept of civil control over the military is complex and multifaceted. It is especially important to understand how the civil control is implemented in practice. In this paper, the analysis mainly focuses on the current state of the democratic civil control over the Lithuanian Armed Forces (LAF) and the civil-military relations. The introductory part gives a short overview of the development of relations between the Armed Forces and the society in independent Lithuania. Special attention is given to the negative effects of the military coup in 1926 on the civil-military relations. The changing status of the Armed Forces around the world and its theoretical and practical implications are also outlined.

The first part of the paper discusses constitutional and legal basis of the civil control over the military and the institutional structure of the National Defence System. The authors in turn explicitly tackle the shortcomings of the executive chain of command and control over the Armed Forces and the parliamentary oversight of activities of both the executive authorities and the armed structures. The analysis rests on the assumption that despite the creation of the legal base (the Law on the Basics of National Security, the National Security Strategy, other legal acts), the practice of the democratic civil control is not fully crystallized and incontestably embedded in the Lithuanian political system. The authors also draw attention to the insufficiently effective parliamentary oversight of national defence institutions.

The second part of the paper discusses the relationship between the civil control over the military and the Lithuanian defence and foreign policy, building on the assumption that civil authorities have full control over foreign policy while the military retain some autonomy over certain professional matters of defence policy. Attention is drawn to the agreement of the parliamentary parties on defence policy priorities. The authors note the influence of cooperation with NATO countries on the development of the LAF in accordance with Western standards. However, the authors differentiate between the requirements of the membership in NATO and the EU with regard to Lithuanian defence policy.

The final part of the paper "The Armed Forces and Society" in more detail discusses the current civil-military relations in the country. The importance of the publicity of Lithuanian defence policy guidelines and the activities of the LAF is emphasized. The authors argue that crisis relief operations should be seen as an indispensable part of the activities of the LAF in peacetime. The special role of non-governmental organizations is also noted in the development of civil-military relations. The role of the media is considered to be positive despite some shortcomings of public information about national defence

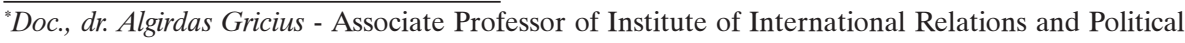
Science of the University of Vilnius. Address: Vokiečiu 10, LT-2001 Vilnius, Lithuania, tel. +3705-2514130,e-mail: algric@1rs.lt

"Kestutis Paulauskas - Graduate Student of the Institute of International Relations and Political Science of the University of Vilnius. Address: Vokiečiu 10, LT-2001 Vilnius, Lithuania, tel. +3705-2514130, e-mail: kestutis.paulauskas@pastas.kam.lt 
policy matters. The authors maintain that academic institutions could play a more significant role in defence and security policy analysis. While discussing the participation of military officers in the political life of the country, the authors contend that the dichotomy between a soldier, who must succumb to the discipline of military hierarchy, and a human or a citizen, who must have certain freedoms and rights, is not an easily reconcilable issue even for consolidated democracies. The resolution of this issue basically depends on the level of political culture and consciousness of the civil society of the country.

The authors conclude that despite some unresolved issues, the civil democratic control over the military has been successfully established in Lithuania. Certain unsettled issues of civil-military relations and insufficiently effective parliamentary oversight over the military structures remain a matter of further consolidation of the democratic political system and formation of civil society. The authors argue that a great number of these issues are inherent to most states and societies in transition.

\section{Introduction: historical context}

At the beginning of the 90's with the dismantling of the Warsaw pact and the Soviet Union itself, a group of Central and Eastern European (CEE) states, including the Baltic States, faced a difficult challenge of the transition to democracy. CEE countries (and the Baltic States even more so) had to reform their political, economic and social order by eradicating and removing the remnants of soviet legacy which was deeply rooted in different spheres of social life and even in the very mentality of people. Given this context, one of the major problems posed by the transition period was the post-Soviet legacy of and within the Armed Forces. Paradoxically, the Baltic States - former Soviet republics - had fewer problems in establishing civil control over their military than did the former Warsaw pact states that were relatively more independent from Moscow. The Baltic States simply did not have any national Armed Forces prior to 1990. They had to build their respective national defence establishments from scratch and thus avoided problems of contentious reforms in the defence sector that other CEE states had to deal with. On the other hand, the Baltic States had barely any historical experience of democracy, and the lack of it could aggravate the democratic transformation process in the nineties.

Indeed the historic record of civil-military relations in the inter-wars period is rather ambiguous. On one hand, the Lithuanian Armed Forces were created on the basis of volunteers who fought for the reestablishment of Lithuanian statehood in 1918-1919. These volunteers withstood attacks of Russian invaders and some Polish military units and this victory granted the Lithuanian military the glory and gratitude of the whole nation. However, with the military coup in 1926, civil-military relations deteriorated. The Parliament (Seimas) was dissolved and the right wing nationalist party leader Antanas Smetona took over the post of the President, in fact becoming the authoritarian leader of the State until the Soviet occupation in 1940. At this period political parties were forbidden and the media - censored. The military establishment enjoyed great autonomy from civil authorities and at the same time was one of the pillars that the authoritarian regime rested upon. These events inevitably affected civil-military relations in the country ${ }^{1}$. However, the gap that emerged between the military and the

\footnotetext{
${ }^{1}$ The authors refer to the memoirs of the former Commander of the Lithuanian Armed Forces (1935 - 1940) Gen. Stasys Raštikis, (see Lithuanian edition: S. Raštikis 'Kovose dèl Lietuvos', Vilnius: Lituanus, 1990, p. 380)
} 
society after the coup, eventually narrowed and practically disappeared before the Second World War. A positive role was played by the media - radio, newspapers and magazines - which were providing the society with a large amount of information about the Armed Forces, their living conditions, military equipment etc. A lot of social events (especially in sports and culture) also facilitated the friendly rapprochement between the military and the society ${ }^{2}$. In 1940, with the failure of the political authorities to declare armed defence against the Soviet aggression, the existence of both the independent State of Lithuania and its Armed Forces ended. Some of the military, however, did start resistance after the end of the Second World War and the partisan war in Lithuanian woods lasted more than a decade.

Under the Soviet regime, the military establishment was closely intertwined with and subordinated to the Communist Party. Such relationship between the military and the state authority could by no means be referred to as the civil control, because there was no civic society itself and its democratically elected representatives. Relations between the society and the 'Red Army' were cold at best. Most of the military serving in Lithuania were conscripts from other Soviet republics, while natives usually were sent to serve outside Lithuania. The height of tension between the Lithuanian society and the invaders army was reached during the bloody events of January $1991^{3}$.

After the independence was restored once again, the Baltic States and to a lesser extent other Central and Eastern European States, had to struggle to build new democratic institutions, new Armed Forces and to establish mechanisms for the civil control over the military. The creation of the national defence establishment of Lithuania started in the first days after the restoration of the independence. The Government of Lithuania founded the Department of National Defence as early as 25 April 1990 - one and a half-months after the declaration of the independence. In 1991, the Department was reorganized into the Ministry of National Defence (MND). The formation of the Lithuanian Armed Forces (LAF) progressed simultaneously. At first they consisted of volunteers and former officers of the Soviet Army. Although initially some residual influence of the Soviet military school persisted within some part of the officer corps, eventually this influence faded away and the LAF strengthened and augmented to become Western-style well-trained national Armed Forces.

Twelve years of freedom and independence provide a more or less sufficient empirical basis for a critical examination of the progress made by Lithuania on the bumpy road towards the consolidation of democracy and its ultimate end - a prosperous civil society. A proper evaluation of achievements and failures of democratic governance in establishing and maintaining the National Defence System can also be made.

\footnotetext{
${ }^{2}$ Ibid, p. 385

${ }^{3}$ On 13 January 1991 Soviet tanks rolled over the unarmed people peacefully protesting at the approaches to the TV tower in Vilnius. 13 people died and many more were injured. Although Lithuania has declared its independence on 11th March 1990, international recognition did not follow until the failure of the military coup in Russia in August 1991.
} 
Studies related to the civil democratic control over the Armed Forces in Europe are financed and coordinated by Geneva Center for the Democratic Control over the Armed Forces (DCAF). Publications and studies of the Center are available on-line ${ }^{4}$. Analysis and studies on the subject of civil - military relations in general and the civil control over the Armed Forces, in particular in Lithuania, were rather scarce up to date. On one hand, the period of the independence has been too short to draw elaborate conclusions on the matter, on the other hand, civil-military relations allegedly have never been a big issue on the political agenda of Lithuania to receive appropriate academic attention. One of the most recent and at the same time one of the few studies on the subject is an article by V. Urbelis and T. Urbonas ${ }^{5}$. This article provides an excellent historical overview of the development of the LAF and the civil control over the military in Lithuania throughout the last decade. Notwithstanding the advantages of the historical analysis and a lot of interesting insights (some of them are also cited in this work), the authors of the study fall short of elaborating on the current persisting problems of the civil control over the LAF within the national security sector. V. Urbelis and T. Urbonas contend that Lithuania has fully completed legal establishment of the principles of the civil control in the laws regulating national security. Although one could hardly disagree with the latter argument, the authors of this work assume that despite the establishment of the legal basis, practical problems of the implementation of the civil democratic control do persist within the Lithuanian political system. The authors hereby seek to contribute to the research of this subject area by presenting a thorough sketch of the current state of affairs of the civil-military relations in Lithuania with a particular focus on the democratic control over the LAF.

\section{Civil-military relations: theory, practice and the international context}

The very concept of civil control over the military is complex and multifaceted to say the least. If the civil democratic control over the Armed Forces is to be comprehended in terms of political control over the military by legitimate, democratically elected authorities of the state ${ }^{6}$, what one has to do is simply look through the Constitution and other basic laws of a given country to determine whether the civil control is in place. However, there is much more to it when it comes to the understanding how successfully (or unsuccessfully) the civil control is implemented in practice. To answer this question the analysis of historical, social, economic, cultural as well as international context becomes instrumental.

\footnotetext{
${ }^{4}$ http://www.dcaf.ch

${ }_{5}^{5}$ See: V. Urbelis, T. Urbonas, 'The Challenges of Civil-Military Relations and Democratic Control of Armed Forces: the Case of Lithuania', in: 'Democratic Control of the Military in Postcommunit Europe', eds. A. Cottey, T. Edmunds, A. Forster, Houndmills: Palgrave Publishers Ltd, 2002, p. 108-125.

${ }^{6}$ The authors draws on the definition offered by A. Cottey, T. Edmunds, A. Forster in 'Introduction: the Challenge of Democratic Control of Armed Forces in Postcommunist Europe', in Democratic Control of the Military in Postcommunit Europe, eds. A. Cottey, T. Edmunds, A. Forster, Houndmills: Palgrave Publishers Ltd, 2002, p. 6
} 
In theory, the civilian control may look simple indeed. Elected representatives and the government must make all major decisions on the defence policy and the Armed Forces of a given country. At least in democracy this should be the case. In practice, however, it is not all that simple. The actual ways and means of how civilians should control their military establishments is an inherent problem for any state, whether a mature democracy or an authoritarian regime. First of all, one must bear in mind the special social status of the Armed Forces - it is a coercive institution, enjoying the monopoly of arms within the state. Moreover, the military is the largest, presumably best financed and best organized social institution in most countries of the world ${ }^{7}$. The structure of the Armed Forces, strict hierarchy of obedience, mandatory conscription and conservative traditions within the military service may seem somewhat opposite to the values that democracy itself stands for. However, given the vital task the Armed Forces are assigned to - the ultimate defence of the Homeland - the society is ready to accept certain deficit of democracy and the exceptional and in some cases privileged status of the military.

At the same time, holding the monopoly of arms, the Armed Forces may represent a major threat to the statehood, which was the case for numerous times in so many different countries of the world. Military coups were a common if not a legitimate practice during the inter-wars period in the larger part of Europe, Lithuania not excluded. Latin America set the all-time record with the peak of 19 governments in countries all over the continent - from Argentina to Mexico - headed by military officers in $1979^{8}$.

During the Cold War, the military exploited certain political power and evident influence over decision making process in both superpowers - the US and the Soviet Union. However, after the Vietnam failure of the former, and the disastrous Afghanistan invasion by the latter, the military establishments of both countries lost a great deal of public credibility and their political influence was also restricted.

The end of the Cold War and its profound impact on international system greatly affected civil-military relations world-wide. Both the US and Russia, as well as most of their allies undertook extensive programs of defence downsizing and conversion ${ }^{9}$. Allegedly more secure yet uncertain international environment led nations to redefine the role of their Armed Forces. The military in many countries were assigned such secondary missions as disaster relief in emergency cases or construction of bridges and highways. Peacekeeping missions in the hot spots of the world became another, more important and more demanding role of the modern military. Peacekeeping is especially challenging in terms of civil-military relations in that the soldiers of any given mission usually have to encounter a foreign and at times hostile society.

Although on one hand, the role of the post-Cold War military has somewhat faltered, on the other hand civilian governments acquired a more firm control over the armed structures in vast majority of countries. In Latin America, there are no military juntas after the civilian rule was restored in Haiti in 1994. On other continents, military regimes like those of Libya, Burma, Nigeria and Pakistan are very rare

\footnotetext{
${ }^{7}$ See: L. W. Goodman 'Civil-Military Relations in the Post-Cold War Era, USIA Electronic Journal, Vol. 2, No. 3, July 1997, http://usinfo.state.gov/journals/itdhr/0797/ijde/goodman.htm ${ }^{8}$ Goodman, op. cit.

${ }^{9}$ For a comprehensive analysis of the effects of military downsizing in the US, Europe and the Soviet Union, see: 'Downsizing Defense', ed. E. B. Kapstein, Washington D.C.: Congressional Quarterly, Inc., 1993.
} 
exceptions. However, there are many other ways in which the military establishment may undermine the democratic rule, not to count authoritarian regimes, which do exploit the army as a tool to exert control over the population.

Even for old established democracies civil-military relations continue to be an issue of the political agenda. How tough or how loose the democratic control should be? How much autonomy and on what matters should the military be granted? These are just a few important questions that Western states are still struggling to answer in a definite way. Even the leader of the democratic world itself - the US experiences certain fears about the implications of the increasing gap between the military and the American society ${ }^{10}$. There is an ongoing debate between two schools of thought: one is associated with S. Huntington who argued for the society adhering to the conservative values of the military, the other suggests "civilianizing" the military in the context of technological advancement and modern warfare ${ }^{11}$.

Major Western European powers are also struggling with their post-Cold War defence reviews and military downsizing. The major issue for France is transition from oversized conscript army to a professional one, expected to be completed by 2015. Germany has only recently overcome its historic and psychological problems that prevented it from full-fledged participation in international military operations. Meanwhile, the United Kingdom is focused on efficient spending and the improvement of the quality of forces.

What is true of Western democracies, it is even more so for new Central and Eastern European democracies. As we have already mentioned, post-communist CEE countries faced great difficulties in reforming their national defence establishments, reconciling their post-Soviet armed forces with the civil society and at the same time preventing them from interference with the domestic policy ${ }^{12}$. The situation further east - in Belarus, the Ukraine and Russia - is a separate big and very problematic issue we are not in a position to address in this paper.

Given the international context of civil-military relations, ranging from military regimes without any democratic control whatsoever to established democracies ever-striving to improve their mechanisms of the civil control, one cannot but conclude that a certain degree of tension between the military and civilians is inescapable. The key problem is the reconciliation of an essentially non-democratic institution within a democratic society ${ }^{13}$. Hence the fundamental question raised by Plato in The Republic and many times recited since: 'Who guards the guards'? Failures in the practice of the democratic control of the 'guards' raise difficult theoretical if not ontological questions about the nature of civil-military relations and their implications on the values of modern but ever-militant civil society ${ }^{14}$.

\footnotetext{
${ }^{10}$ See: O. R. Holsti 'A Widening Gap between the U.S. Military and Civil Society?', International Security, Vol. 23, No. 3, 1998/99

${ }^{11}$ See: J. Matus 'Civil-Military Relations and Decision-Making on Defense', Lexington: Virginia Military Institute, 2001

${ }^{12}$ See: 'Democratic Control of the Military in Postcommunist Europe: Guarding the Guards', op. cit. This book contains collection of essays on situation of civil-military relations in most CEE countries.

${ }^{13}$ We owe this argument to Ch. Donnelly 'Defence Transformation in the New Democracies: A Framework for Tackling the Problem', NATO Review, No. 1, Jan. 1997

${ }^{14}$ For perhaps the most elaborated general theory of civil-military relations see the classic work by Samuel P. Huntington 'The Soldier and the State: the Theory and Politics of Civil-Military Relations', London: the Belknap Press of Harvard University Press, 1998
} 
On one hand, the civil control over the military can be considered as a prerequisite for the democratic rule, on the other hand, the civil control itself occurs as the result of a consolidated democratic political system. Raison d'etre of the civilian control is to make security and defence matters subordinate to major purposes of a given nation, rather than the other way round. The purpose of the Armed Forces is to serve and defend the society from which they are drawn, not to restrict $\mathrm{it}^{15}$. This is why it is of crucial importance for transitional democracies to develop relevant procedures and tools of the civil control over the Armed Forces. Various authors argue for different requirements of the civil democratic control to be efficient. However, most of them agree on the following three sets of criteria that must be met to make it functional:

- democracy as such must be a given within the state: the rule of law, separation of executive, legislative and judicial powers, human and civil rights and liberties, free democratic elections are all crucial elements for mere functioning of the civil control;

- clear subordination of the Armed Forces to the Government and accountability to the Parliament (which in turn implies the accountability to the people); - political neutrality of the Armed Forces and abstention from any interference with internal affairs, ensured by legal punishments for violations of the civil control, credibly backed up by other armed institutions (police and security services) as a countervailing power.

We will further argue that all these criteria are fulfilled within the Lithuanian institutional settings.

\section{Institutional settings for the civil control over the Lithuanian Armed Forces}

The transition towards democratic structures and procedures in Lithuania to a large extent was a story of success: with the democratic constitutional order firmly established, the military establishment subordinated to the civilian authority and accountable to the legislators, and relatively strong political neutrality of the Armed Forces, there is no question or doubt whether there is the civil democratic control of the Armed Forces in Lithuania or not. However, the record of its actual performance is another matter, which requires a more detailed examination. In order to do this, two intertwined dimensions must be tackled: legal and institutional framework of the democratic control of the military and functional relationship between the national defence system and the state's defence and foreign policies, as well as the role of the military in domestic policy and within the society. We will first focus on the institutional settings of the Lithuanian national defence establishment: 1) constitutional and legal bases for civil control; 2) executive control of the LAF and 3) parliamentary oversight of the activities of both: executive authorities and the armed structures. Building on this analysis, we will then discuss implications for Lithuanian foreign and defence policy.

\footnotetext{
${ }^{15}$ This clause is firmly embedded in Lithuanian law as well: the Law on the Basics of the National Security explicitly states that the Armed Forces shall be loyal to the Republic of Lithuania, its Constitution, serve the State and society, obey the government democratically elected by the Lithuanian citizens (see: Chaper 18 of the Law. English translation of the Law may be accessed via internet at the following web address: http://www.kam.lt/en/main.php?cat=ministerija\&sub=6 ).
} 


\subsection{Legal framework}

The rule of law principle is essential precondition for the implementation of democratic control of the Armed Forces ${ }^{16}$. Moreover, the rule of law is an equally important premise for democratic control of the Armed Forces both in old democracies and transitional states. The constitutional and legal provisions on the competencies and responsibilities of different state institutions with regard to the defence establishment and mechanisms of supervision and accountability are of crucial importance for any democratic state.

It is obvious that there was no legislative basis whatsoever regulating national security and military matters prior to the adoption of the Constitution on 13 October $1992^{17}$. The Constitution was also not very explicit on the subject. However Chapter XIII of the Constitution did establish basic provisions of the national defence. According to Article 140 of this Chapter, the State Defence Council, consisting of the President (the Chair of the Council), the Prime Minister, the Chairman of the Parliament, the Minister of National Defence and the Commander of the Armed Forces, discuss and coordinate the main issues of the national defence. The same Article clearly and unambiguously establishes direct responsibility of the Government, the Minister of National Defence and the Commander of the Armed Forces to the Parliament for the management of the Armed Forces of Lithuania. This provision may be considered the legal cornerstone of the civil control in Lithuania. Article 140 also names the President as the Supreme Commander of the Armed Forces of Lithuania and forbids the appointment of an active serviceman as the Minister of National Defence. Among other important provisions, the Constitution establishes the right and duty of the Seimas to impose the martial law, declare mobilisation, decide on the usage of the Armed Forces for the defence of the Homeland or on the implementation of international commitments (see Article 142 of the Constitution).

After these fundamentals were laid down, a more explicit and detailed legislative basis was slow to develop causing certain practical-technical difficulties to the formation of the National Defence System. Paradoxically enough, the civil control was the guiding principle in the development of the Lithuanian National Defence System despite the lack of legal basis and the absence of clear understanding of the very notion of what the civil control implies to the civil - military relations. As mentioned before, Lithuania as well as two other Baltic States, started the formation of their respective Armed Forces from scratch. Needless to say, civilian authorities were in the lead of this process. The civilian leadership, for example, prevented the ill-designed practice of establishing the Commander of the Armed Forces as the main person guiding and controlling the Armed Forces. Although such a position did emerge in the structure of the national defence establishment in 1993 (partly due to the historical legacy), it was directly subordinated to the $\mathrm{MND}^{18}$.

\footnotetext{
${ }^{16}$ For comprehensive study of legal aspects of civil control of the military see: 'Legal Framing of the Democratic Control of Armed Forces and the Security Sector: Norms and Reality/ies', ed. B. Vankovska, Belgrade: Goragraf, 2001

${ }^{17}$ English version of the Constitution of the Republic of Lithuania may be accessed via internet at the following web address: http://www3.lrs.lt/c-bin/eng/preps2?Condition $1=21892 \&$ Condition $2=$ ${ }^{18}$ In common practice of Western countries the Head of the Armed Forces is the Chief of Defence (CHoD). In Lithuania the duties of the CHoD are split between the Chief of Defence Staff, the Commander of the Armed Forces and the Land (Field) Forces Commander.
} 
However, it was not until the adoption of the Law on the Basics of National Security in 1996 that the practical achievements of the civil control were embedded in what is now considered to be the quintessential law of the national security of Lithuania. Chapter 8 of this Law elaborated and developed the provisions of the Constitution concerning the civil control. The Chapter reinforces the constitutional provision that all decisions on defence policy and the Armed Forces are to be made by the democratically elected civilian government, adding that defence policy and defence expenditure must be made public. It also states that not only the Minister of National Defence may not be an active serviceman, but the same also applies to the Minister of Internal Affairs, their Vice-Ministers and the Director of the State Security Department. The Law explicitly establishes the main principles and procedures of the executive command and control over the Armed Forces. The Seimas in its own right is entitled to the parliamentary control, regulating by law and disciplinary statutes the activities of the Armed Forces and other national security institutions, including the State Security Department and the police force. However, the Law failed to establish a clear definition of the parliamentary oversight and provided only limited tools of accountability and control.

The legal basis of the national security of Lithuania was further consolidated with the adoption of the Law on the Organisation of the National Defence and the Military Service in 1998. Only now it was explicitly established in a legal act that the Seimas determines the amount of funds to be allocated for the development of the Armed Forces, the acquisition of weapons and other support equipment. The Law once again emphasized that the national defence policy and allocation of funds approved by the Seimas for defence must become part of the public record. The Law did not introduce anything new in terms of executive control just paraphrasing provisions established by the Law on the Basics of National Security.

The Military Defence Strategy, which was approved by the State Defence Council in October 2000, was by no means innovative in terms of specific provisions of the civil control. However, the document established the democratic civilian control over the LAF as one of the four fundamental principles of the Lithuanian defence policy, along with deterrence, total and unconditional defence and Euro-Atlantic solidarity with regard to collective defence. It is noteworthy, that priority among these was given to the civil control highlighting it as the cornerstone of the Lithuanian defence policy.

The formation of the legal system of national security was crowned by the adoption of the National Security Strategy of the Republic of Lithuania on 28 May 2002. As all legal provisions concerning the civil control over the LAF were already in place, the Strategy only reiterated that the democratic control is one of the basic concepts of the Lithuanian defence policy. In spring 2002, officials of the MND declared the Partnership Goal of the NATO Planning and Review Process (PARP) regarding the application of the legal system completed. However, the process of the formation of the legal basis was not so smooth as one may assume: it took a dozen years to adopt the National Security Strategy, which should have been the basic initial document of the national security policy and planning. On the other hand, the formation of the legal system should be considered as a continuous process rather than a final definite outcome. 
The mere existence of a constitutional and legal framework for the democratic control over the Armed Forces may be seen as a sufficient condition for meeting formal democratic criteria. However, in practice it may not function at all if it is not set up in a democratic environment, where efficient democratic political institutions are a given and a conscious civil society is at least emerging if not yet in place. The major problem the states in transition and Lithuania among them face is not the absence of legal norms, but first and foremost their unsatisfactory or ill-defined implementation. There is a scope of political, social, technical and even cultural limitations to the legal framework as a means to execute democratic control over the national security sector. These are examined below.

\subsection{The executive chain of command and control}

The central principle of the civil democratic control over the military is that the Armed Forces must under any circumstances remain clearly subordinated to the Government. The authors consider the following principles as the main minimal requirements for the functioning executive control over the Armed Forces:

1) a clear chain of command with civilian leaders at the head;

2) a civilian Minister of Defence and the Ministry itself at least partly staffed by civilians;

3) subordination of the Defence Staff to the Ministry of Defence.

All these elements are in place within the National Defence System of Lithuania. The chain of command of the National Defence System of Lithuania is provided in the chart below.

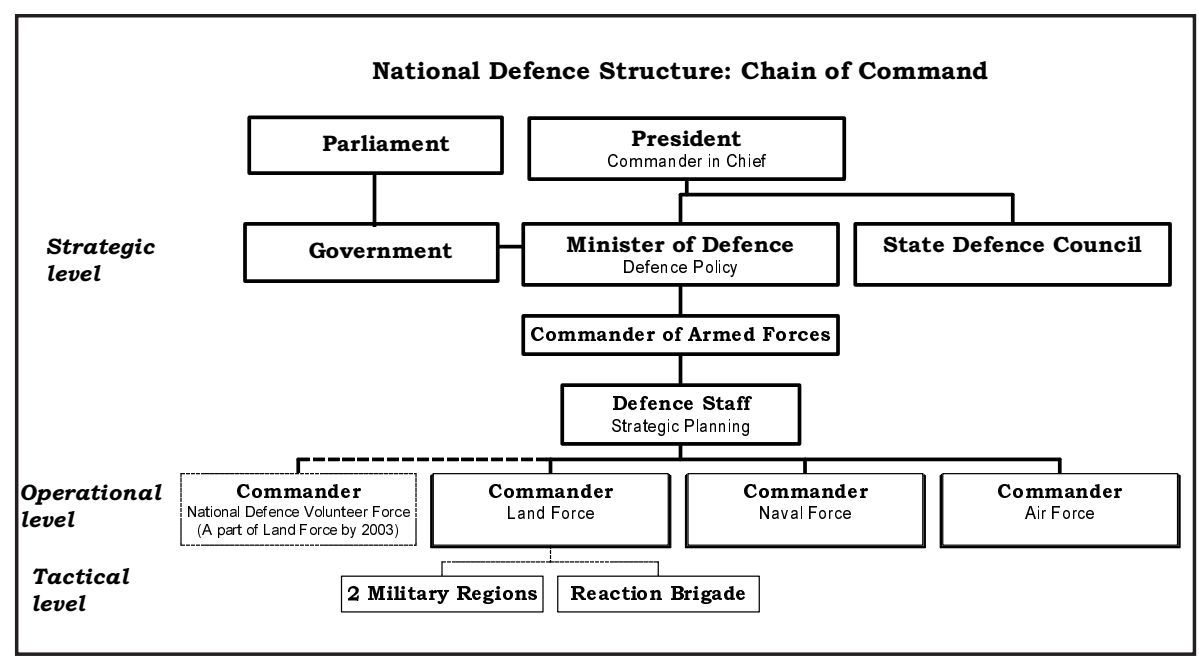

In democratic countries the armed services usually owe ultimate allegiance to the Head of State as the embodiment of the nation ${ }^{19}$. Lithuania is no exclusion: the President of the Republic of Lithuania is the Supreme Commander of the Lithuanian

\footnotetext{
${ }^{19}$ M. Quinlan 'The Role and Oversight of Armed Forces Within Democratic Societies', NATO Review, No. 5, Vol. 41, Oct. 1993
} 
Armed Forces. In the event of an armed attack against the State or when a threat arises to the sovereignty or the territorial integrity of the State, the President makes an immediate decision on defence against the armed aggression, introduces the martial law, declares mobilization and submits these decisions to the Seimas for approval ${ }^{20}$. Besides these shared responsibilities, the President chairs the State Defence Council; upon the approval of the Seimas he also appoints the Commander of the Armed Forces and upon the approval of the Minister of National Defence appoints the Field (Land) Force Commander, grants high military ranks (ranks of colonel and higher) and decorates distinguished military personnel with orders.

It is obvious that the President cannot and should not personally run every aspect of the command over the Armed Forces. The Government through the Minister of National Defence carries out direct control over the military establishment. The Government as such, however, performs rather few yet important functions of the executive control. The Government or its authorized institution issues resolutions on supplying the Armed Forces, procurement of weapons, and the development of a logistical base of support within the National Defence System ${ }^{21}$. Besides these general functions, the Government has no other specific role in carrying out civil control. After all, this is what the Minister of National Defence stands for - there needs to be a clearly defined person being fully responsible within the Government for all defence matters on whom the nation and the Parliament on one hand, and the Armed Forces on the other, can rely ${ }^{22}$.

Indeed, the Minister of National Defence of Lithuania may be considered as the central figure of the whole national defence establishment and the MND as the central institution thereof. The Minister is fully responsible for the implementation of defence policy, development of the National Defence System and the international defence-related cooperation ${ }^{23}$. As it was already mentioned, the Minister and the Vice-Minister can't be active servicemen. However, the "civilianisation" of the ministerial personnel does constitute a challenge for the civilian executive control over the military. A shortage of civilian personnel with relevant defence expertise was a chronic problem throughout the last decade, as a result military personnel held key positions in the Ministry and made key defence policy decisions ${ }^{24}$. Although the goal of the personnel management policy is to achieve an optimum balance between the civilian and military staff, the current balance with $52 \%$ of the personnel being civilian and $48 \%$ - military is not satisfactory. Furthermore, the practice of appointing active military servicemen as heads of key policy departments (for example, NATO Department and Defence Policy and Planning Department) is an ill-designed

\footnotetext{
${ }^{20}$ See the Law on the Basics of National Security, Chapter 13, http://www.kam.lt/en/ main.php?cat $=$ ministerija $\&$ sub $=6$

${ }^{21}$ See the Law on the Organisation of the National Defence System and the Military Service, Chapter 7, English version at the following web address: http://www.kam.lt/en/main.php?cat =ministerija\&sub $=6$

${ }^{22}$ M. Quinlan, op. cit.

${ }^{23}$ The functions of the Minister are explicitly laid out in the Law on the Organisation of the National Defence System and the Military Service, Chapter 10, http://www.kam.lt/en/main.php?cat=ministerija\&sub $=6$

${ }^{24}$ V. Urbelis, T. Urbonas, 'The Challenges of Civil-Military Relations and Democratic Control of Armed Forces: the Case of Lithuania', op. cit., pp. 117-118
} 
endeavor hardly reconcilable with the principle of the civil control. The underlying cause of such personnel policy was lack of experienced and qualified civilian personnel with relevant background. In the future, however, it should not be an excuse anymore with an increasing number of young civilian specialists with relevant education graduating from Lithuanian and/or Western universities and eventually gaining necessary experience in the National Defence System. Policy of the "civilianisation" of Ministry personnel must be carried on, yet it is not to say that professional military expertise is not necessary within the Ministry - in certain matters it is irreplaceable. However it is an imperative principle of the civil control that decision making in defence policy is a prerogative of civilian officials.

Another tier of the executive chain of command and control of the Armed Forces consists of the Commander of the Armed Forces and the Defence Staff - the main military body guiding the preparation and development of the Armed Forces. With the review of the structure of the Armed Forces being carried out in accordance with NATO standards the Commander may be seen as questionable ${ }^{25}$. Although initially the laws envisaged a very important role for the Commander, most of the 23 functions of this position set out in the Law on the Organisation of the Armed Forces and the Military Service are in practice delegated to and carried out by either the Chief of Defence Staff or the Land Force Commander.

The Defence Staff is considered to be an integral part of the MND. Although the principle of subordination of Defence Staff to civil authorities (i.e. the Minister and Vice-Minister) is observed, in practice certain questions about the 'integrity' may be raised. Indeed, sometimes the Defence Staff and the Ministry appear to work as two separate institutions rather than an integral body. Some of these problems are attributable to the lack of coordination. Formally, the Defence Staff is subordinated to the Commander of the Armed Forces while he in turn reports to the Minister. In practice, this means an intermediate tier of command that aggravates the command, control and communication link between the Ministry and the Defence Staff rather than facilitates it. In the worst case, this position may become a source of friction. The Commander of the Armed Forces is a political appointee, nominated by the President upon the approval of the Seimas for a 5-year term of service, while the Minister is appointed for a 4-year term but in fact his term in office depends on the political situation in the Parliament, which is fluid at best ( 12 Governments have changed in the 12 years of independence).

To conclude, it should be made clear, that the said shortcomings of the executive control do not in any way threaten the stable and positive overall situation of civil-military relations within the National Defence System in general and the democratic control over the Armed Forces in particular.

\footnotetext{
${ }^{25}$ In most NATO member countries the position of the Commander of Armed Forces does not exist. Chief of Defence Staff in most cases is the supreme military authority.
} 


\subsection{Parliamentary oversight}

If in the case of the executive chain of command and control there are clearly identifiable requirements, usually common to most democratic states with minor nuances, there are wide differences in the ways the elected legislature performs the parliamentary oversight. The role of the Parliament may differ from active involvement in every aspect of defence policy and military affairs even making executive decisions (such as weapons procurement or participation in an international operation) to mere monitoring and awareness of the endeavors undertaken by the Government. Whatever the actual arrangements, the parliamentary control over the military is usually twofold: the Parliament provides for the general oversight of the Armed Forces; at the same time, the Parliament must ensure control over the executive authorities (the President and the Government / MND) implementing defence policy.

Today, all legal premises for effective parliamentary control over the security sector are in place in Lithuania: there is a sufficient quantity and quality of laws and legal norms establishing procedures for the parliamentary oversight. However, this area of the civil control notwithstanding its crucial role actually faces some major difficulties and shortcomings. A priori it should be noted that some of these problems are inherent in many other democratic states both mature and transitional.

The Law on the Basics of National Security has established the main functions of the Parliament in ensuring the civil control over the defence sector: the Seimas determines the organisation, development, armament needs of and assignations to the Armed Forces. As J. K. Giraldo put it in a vivid manner, "the power of the purse provides civilians with a key lever of control over the military: government preferences are more likely to be taken into account when they are backed by the provision or withholding of resources"26. Indeed the Parliament has the ultimate power to allocate budgetary expenditures. Once again, when it comes to the actual management of defence financial resources, the picture becomes somewhat blurred. Although the final approval of the States' budget (and thereof defence budget) is maintained by the Seimas, in practice the possibilities of the parliamentarians to significantly alter the expenditure allocations are rather limited due to the lack of knowledge and expertise. It is obvious that the civilian and military officials of the MND are better informed about particular needs of the Armed Forces and better prepared to protect financial claims of the military. However, it is also obvious that certain ministerial claims for State's assignations might be exaggerated or not of primary importance. Given limited financial resources of Lithuania and an urgent need to balance the State's budget, the efficient and rational allocation of funds for defence purposes is an imperative.

One can observe that the national defence establishment is becoming a consolidated and strong lobbying institution, which sometimes behaves as a lobbying group rather than an impartial governmental institution. The following instance also prompts to such a conclusion. At the end of every year the MND submits the draft Law on the

${ }^{26}$ J. K. Giraldo 'Defence Budgets and Civilian Oversight', Occasional Paper No. 9, Monterey: The Center for Civil-Military Relations, Naval Postgraduate School, 2001 
Principle Structure of the Armed Forces of the Republic of Lithuania. This is an important annual document setting limit numbers of the personnel in the Armed Forces, including conscripts, professionals, non-commissioned officers and officers. Every year, heated discussions revolve around this Law in the Parliament with different opinions being raised as to what kind of the Armed Forces Lithuania needs: a small professional force or a large conscript Army. Any attempts made by the parliamentarians to amend the draft Law are usually met by strong opposition from the representatives of the Ministry, bearing on the assumption that any changes in the numbers proposed by the MND would ruin long-term defence planning and would be disastrous to the whole national defence establishment. In the end of the day, the Seimas usually adopts the Law without any amendments. The conclusions that follow from this example are rather mixed. On one hand, it is evident that the national defence establishment is becoming a strong lobbying group seeking to maintain autonomy on certain defence policy matters and the structure of the Armed Forces. On the other hand, the officials of the National Defence System seem to comply with the rules of the political process set by the democratically elected authorities. They never infringed the rules of lobbying for the legitimate interests of their institution. This should be regarded as a positive trend in the ongoing formation of the political system, however time is needed for such behavior to become a routine inherent in the civic political culture of Lithuania. Besides, the line between the legitimate lobbying and unlawful interference is extremely thin and therefore should be observed with adequate caution.

The process of drafting and approving the National Security Strategy - the most important document on national security - may be presented as yet another symptomatic illustration of imbalanced relationship between the Government / MND and the Parliament. The Seimas had little opportunity to influence the whole process. On one hand, the actual drafting of the Strategy has been carried out within a small group of experts from governmental institutions (the MND, the Ministry of Internal Affairs, the Ministry of Foreign Affairs and the State Security Department) with little public knowledge or any significant interaction with the Parliament. The Government submitted the final product to the Seimas for a rather symbolic approval. The question arising here is that of the leverage between the efficiency and legitimacy: the former should not be sought at the expense of the latter. Some balanced combination of the two must be found.

The authors of this research believe that the underlying cause of the abovediscussed issues is the lack of expertise. There is indeed an urgent problem of experts and advisers to the parliamentarians. However, it should be noted that this problem is inherent to many new democratic states. Few civilians in most transitional democracies have the knowledge and understanding of the military affairs to serve as civilian-defence policy experts ${ }^{27}$. Moreover, civilian expertise is an urgent need given the current post-Cold War security environment. The revolution in military affairs, which is taking place worldwide is based on high-tech sophisticated technologies and favors smaller, mobile forces. This is the target goal of the ongoing review of the LAF as well. Any reform (and reform in the defence sector even more so) may trigger sensitive social issues such as wages and employment. Although downsizing of the LAF is

${ }^{27}$ For further argumentation see: L. W. Goodman, op. cit. 
not on the agenda of the Lithuanian defence policy, however it is sought to limit spending on the personnel to not more than $50 \%$ of the defence budget, reallocating resources to procurement and defence infrastructure ${ }^{28}$. For the reform to go on smoothly, civilian authorities must understand military needs, as well as military officers have to be aware of the necessity of political decisions taken by civilians. This is why civilian expertise is crucial for efficient functioning of the democratic control.

Another problematic issue of the democratic control is that of transparency in procurement. The Parliament does not have any role in procurement process whatsoever. It is not to say that the Parliament should interfere when the Government is purchasing radios or shoes for the LAF. Yet when a pending tender of some major weapons amounts to a considerable portion of the defence budget, the Parliament should at least be notified and at best should take the decision on procurement. This is a common practice in many Western societies and some of CEE countries. Although this way the process of procurement would be prolonged with possible postponements and even cancellations, it would ensure transparency and accountability, preventing obscure tenders and ever-feasible corruption. But once again, at this point the Seimas lacks the necessary expertise, and the LAF would be the one that would suffer at the expense of more transparent and allegedly "better" democratic oversight $^{29}$. If improvement in terms of civilian expertise within the Parliament took place, a certain role for the Seimas in procurement process would be imperative.

Last but not least the issue that needs to be addressed in the context of parliamentary oversight is the democratic control over security structures other than the LAF, first and foremost intelligence services. The role of the Parliament in this sphere is also limited partly due to objective reasons. Activities of the intelligence services have to do with sensitive issues of the national security of the State and State secrets above all. Therefore, the civil control over these services requires different arrangements than that of the Armed Forces or the police force. Chapter 20 of the Law on the Basics of National Security contends that the State Security Department, an institution conducting foreign intelligence and counter-intelligence, is accountable to the Seimas and the President of the Republic. The budget, resources, methods and equipment of the Department are considered a State secret. Therefore, the Seimas exercises parliamentary control over the Department's activities in compliance with the requirements of the protection of state secrets.

The Second Department of the Operational Services under the auspices of the MND is an institution conducting military intelligence and counter-intelligence. Up to date, the Parliament did not have any role in controlling this Department, which is directly responsible to the Minister of National Defence. Without any parliamentary oversight in place, under certain circumstances this Department may become a source of uncontrolled political power and may be used in inappropriate ways. Although

\footnotetext{
${ }^{28}$ See 'The guidelines for development of the Lithuanian National Defence System for the year 2002-2005 (Defence guidelines)', Ministry of National Defence of Republic of Lithuania, Vilnius 2001, p. 18

${ }^{29}$ The authors here would like to draw on the example of the Parliament of the Czech Republic, which recently failed to complete a major tender of procurement of Swedish Gripen fighters. Due to the politicization of the issue and apparent lack of defence experts in the Parliament, the decision has been postponed to the newly elected government, which is likely to choose another supplier.
} 
the likelihood of such a course of events is extremely small, a relevant and acceptable mechanism of parliamentary oversight of this institution (perhaps similar to the one applied to the activities of the State Security Department) must be established.

Institutional arrangements of the civil control over the military are just one side of the whole story. The State's domestic, foreign and defence policy is another important dimension of the democratic control that sometimes tends to be overlooked ${ }^{30}$.

\section{Lithuanian foreign and defence policy: implications for the democratic control}

While in case of domestic policy civil-military relations do not pose any significant trouble (the military are more or less efficiently prevented from interfering into internal political affairs) foreign policy and defence policy in particular are somewhat more contentious issues.

If defence policy is to be understood in broad terms as the overall development of the Armed Forces, encompassing defence budgeting, force structure, arms procurement as well as military defence strategy and planning, most of these elements were already discussed throughout the article. To summarize, the basic feature of the Lithuanian defence policy is a certain balance between a strong civilian leadership over general policy guidelines and the military retaining relative autonomy on certain exclusively professional military matters. The recent national political consensus over a long-term direction of the Lithuanian defence policy deserves a special mention. In May 2001, the parliamentary parties of Lithuania signed an agreement on defence policy priorities for the period 2001-2004 ${ }^{31}$. This national accord finally and irreversibly ended a decade-long ever-reemerging dispute about the direction the Lithuanian defence policy should take. The document stipulated that 'the national security and defence system of Lithuania are developed as part of the common European security and trans-Atlantic defence systems'. The parties also agreed on a stable defence financing at 2\% of GDP for the period 2002-2004.

With civilians being appointed to top positions of the National Defence System, military officers have little to no opportunity to significantly alter the general direction of the defence policy. At the same time, certain issues like force structure, defence plans or intelligence require professional military expertise while civilian interference should be limited to mere oversight. In the case of foreign policy, the role of the military is even more limited, yet fairly important. First of all it has to do with the use of a military force outside the Homeland. There is a widely spread stereotype that the military are more prone to see military threats and use armed force in solving international disputes than their civilian counterparts. Some argue this is the reason why a strong democratic civilian control becomes so vital for preser-

\footnotetext{
${ }^{30}$ For example, the cited article by V. Urbelis and T. Urbonas did not elaborate on this problem at all.

${ }^{31}$ See 'Agreement between the parliamentary parties of Lithuania on the defence policy, 20012004', the Ministry of national defence of the Republic of Lithuania, Vilnius, 2001
} 
ving peace. Valid or not, this assumption does not pose any trouble to Lithuania. All foreign policy decisions are firmly in the hands of civil authorities. According to the Constitution (Chapter 84) the President takes main decisions on the foreign policy and together with the Government implements them. All decisions on the use of the Armed Forces are made by the Parliament and in an emergency case by the President (and later approved by the Parliament). Although the LAF did not participate in any combat encounter with an enemy after the restoration of the independence, since 1994 Lithuanian troops have been taking part in peace support missions, including UNPROFOR, IFOR, SFOR and most recently KFOR. The defence establishment is also directly represented abroad via the institution of the defence attachés ${ }^{32}$. Activities of the latter, however, are limited to bilateral defence-related cooperation.

A proper analysis of the implications of the civil control over foreign and defence policy of Lithuania may not be detached from the international context. Democratic control in transition countries faces double challenges: it needs to be introduced and implemented for the first time in national settings and it longs to catch up with the new developments in supra-national setting that is being created in the Western security community ${ }^{33}$. Indeed, incentive given by the cooperation with NATO has played an important role in establishing the legal framework of the civil control over the defence sector in CEE countries and Lithuania among them. It should be noted however, that Western patterns were neither blindly copied nor were they directly applied in transition states given the varying local features and peculiarities of national defence systems.

Sometimes the concept of the civil control is misinterpreted by the general public or media as a NATO requirement which otherwise the State would not need to observe. Instead it is rather a crucial de facto prerequisite without which NATO membership of one or another country and the actual requirements it should meet would not even be considered. Moreover, the civil democratic control over the military is crucial for mere existence of the democratic constitutional order. However, the international context and the implications of outside pressures may not be neglected as well. There is a basic consensus among NATO member states that the Alliance shall not impose common solutions and models of the democratic control over the Armed Forces to other countries. NATO attempts to combine and reconcile the principles of state sovereignty, democratic control and multinational military structure. NATO's PARP under the Partnership for Peace (PfP) program along with the Membership Action Plan (MAP) may be considered as facilitating vehicles for introducing democratic standards in defence establishments of partner and aspirant states. Therefore, pursuing NATO membership as the strategic goal of the Lithuanian defence policy continues to have a considerable impact on the development of civilmilitary relations in the country.

Another factor of external influence on foreign and defence policy is the process of the integration of Lithuania into the EU. Lithuania expects to join this organi-

\footnotetext{
${ }^{32}$ Up to date Lithuania has accredited 8 defence attachés in 16 NATO member countries, 9 in partner countries, and has military representatives in NATO and the EU.

${ }^{33}$ See: 'Legal Framing of the Democratic Control of Armed Forces and the Security Sector: Norms and Reality/ies', ed. B. Vankovska, Belgrade: Goragraf, 2001, p. 11
} 
sation in 2004. Due to the supranational character of the EU, implications of its membership on Lithuanian foreign and defence policy allegedly should differ from those of NATO membership. Lithuania has already closed the negotiation chapter on Common Foreign and Security Policy (CFSP) undertaking certain commitments in this regard. However, having in mind the latent character of the CFSP formation process and lack of the collective defence dimension, NATO membership is considered to be the cornerstone of the national security of Lithuania in the future and therefore military standards of the Alliance prevail in the ongoing development of the LAF.

\section{The Armed Forces and the Society}

The domestic political function and position of the military within the society forms one of the core components of civil-military relations ${ }^{34}$. Above all the Armed Forces have to be accountable to the society they were created to defend. However, one has also to bear in mind, that the ideal of the democratic control is a two-way process, a constant exchange between the Army and the society, not one where politicians simply dictate to soldiers ${ }^{35}$.

The Law on the Basics of National Security states that "the national defence policy and defence expenditure shall be public knowledge". In line with this provision, the MND has undertaken what one may call the strategy "of going public". Different booklets, brochures and posters are aimed at increasing public awareness of the defence affairs in general and NATO integration in particular. The Ministry also finances editions of specialized literature: the newsletters - "Krašto apsauga" ("National Defence"), "NATO žinios" ("NATO News"), the monthly and quarterly magazines "Karys" ("The Soldier"), "Kardas" ("The Sword"), "Trimitas" ("The Trumpet"). The relations between the national defence establishment and the public media are not ideal, but there is no evidence of tension between the two either. The media in general supports the course of Lithuanian's integration into Euro-Atlantic institutions and therefore avoids severe criticism of the national defence and security policy. Yet there is an evident lack of analytical articles on the LAF, NATO integration and similar matters. Minor accidents within the Armed Forces usually attract much more media attention than some important international exercises taking place on the Lithuanian soil. This problem is attributable to the lack of expert journalists in military affairs and the immature state of Lithuanian journalism as a whole.

The Armed Forces, in their turn, carry out "the open door" policy by organising and participating in many social events on different formal (National festivals) and informal (for example, presentations of movies on military themes) occasions and above all the celebration of the Day of the Armed Forces - 23 November. During such events, both the military and civilians have an opportunity of direct intercourse. Exhibitions of military transport, hardware and weapons, a huge bowl of the so-called "military porridge" and similar attractions as nothing else enhance mutual understanding and trust between the society and the Armed Forces.

\footnotetext{
${ }^{34}$ See: A. Cottey, T. Edmunds, A. Forster, op. cit. p. 6

${ }^{35}$ Ch. Donnely, op. cit.
} 
Another not so visible yet very important area of civil-military cooperation is search and rescue operations. Every now and then, civilian institutions call for the help of the Armed Forces in cases of natural disasters and accidents: floods, storms etc. Sometimes as a sign of goodwill or as a part of training exercises some military units assist people by building pontoon bridges and providing similar help.

The last but not least important issue of civil-military relations is the role of the so-called third sector non-governmental organisations (NGO). Although the participation and influence of the NGO on the discourse of civil-military relations and on defence policy issues was rather limited up to date, their informal role is increasing. One of the most prominent NGO is the Lithuanian Atlantic Treaty Association (LATA), which organises round table discussions and conferences on different aspects of the Lithuanian integration into NATO. The Institute of International Relations and Political Science and the Institute of Strategic Studies under the auspices of the Military Academy are emerging as "think tanks" on strategic issues of the national security and defence. For example, in June 2002 the Institute of International Relations and Political Science in cooperation with the Center for Strategic and International Studies (based in Washington D.C.) prepared an extensive study 'Lithuania's Security and Foreign Policy Strategy'.

All these efforts contribute to increasingly favorable attitude of the society to both the LAF and NATO. The dynamics of the polls show that the trust of the public in the military was constantly rising throughout the last decade. According to the current public polls, the Armed Forces of Lithuania constantly rank fourth among social institutions with 40-46\% of public approval (trailing only behind the Church, the media and the President, but surpassing health care, social insurance, police, the courts and the Government) ${ }^{36}$. In addition, about $60 \%$ of the population support Lithuania's NATO membership bid.

One of the indicators of the growing popularity of the Armed Forces and the military profession itself is the increasing competition among those willing to enter the Military Academy of Lithuania. The entrance competition to this academic institution is one of the biggest in the country. One could even contend that the profession of a military officer is becoming a respectable and the Armed Forces - an indispensable part of the Lithuanian society.

It is noteworthy, however, that in the early years of the independence there was a widespread public disillusionment and negative attitudes towards the Armed Forces generated by some criminal offences, involving corruption and financial machinations, committed by the military or defence officials ${ }^{37}$, mostly those connected with the Soviet past. Other incidents were related to a high degree of politicization of the Voluntary Service of the National Defence (VSND) - paramilitary force, at the time almost personally loyal to the right wing Homeland Union and its leader V. Landsbergis. Upon the appointment of L. Linkevicius the Minister of National Defence at the end of 1993, the course was taken towards complete and irreversible depoliticization of the LAF, and the VSND was eventually reorganized and integrated into the structure of the regular Armed Forces.

\footnotetext{
${ }^{36}$ On 18th of May 2002 the Armed Forces of Lithuania favored $42.6 \%$ of public confidence (see: 'Lietuvos rytas', 18 May 2002, No. 113)

${ }^{37}$ For more details, see: V. Urbelis and T. Urbonas: 'The Challenges of Civil-Military Relations and Democratic Control of Armed Forces: the Case of Lithuania', op. cit., pp. 110-111
} 
Today Lithuanian military are barred from the participation in the political life of the country. First of all, this clause has to do with membership in political parties. However, the dichotomy citizen-soldier is not an easy issue to handle even for consolidated democracies. There is no doubt that certain things civilians can do are not proper to the military. However, there is another side to the story: basic human rights which should not be undermined under any circumstances. The freedom of speech and the right of self-expression are at the very core of democracy. Democracy as such implies the protection and implementation of the basic human rights of individuals whether they are civilians or military officers. In this sense participation of the military in social and political life is one of the most contentious issues. These issues basically depend on the level of political culture and political consciousness of the civil society. It may require some time for democratic norms and values to be enshrined in everyday life of the Lithuanian society.

\section{Conclusions}

The civil democratic control over the military has been successfully established in Lithuania during the last dozen years. However, certain unresolved issues of civilmilitary relations remain a matter of further consolidation of the democratic political system and formation of the civil society in the country. Some of these have to do with the specific socio-political context of Lithuania, while other issues are of a more general nature, i. e. inherent to most democratic societies and states in transition.

The record of civil-military relations of the inter-wars period (1918-1940) and the military coup of 1926 barely had any significant influence on the process of the formation of modern Armed Forces of Lithuania in the nineties. After the restoration of statehood, Lithuania managed to create modern Armed Forces based on the model and virtues of Western democracies in a rather short period of time. The influence of Soviet legacy, which initially persisted within the military establishment, eventually faded away. Lack of historical experience of democratic governance was not that big an issue, as some may have feared initially. All the necessary legal mechanisms for the democratic civil control over the Armed Forces are firmly embedded in the Constitution and other laws regulating activities of the national defence establishment and the LAF. However, a thorough analysis of the civilian control over the Armed Forces in Lithuania enabled the authors of this article to highlight certain shortcomings rather than problems of the civil control, still persisting in the national defence establishment of Lithuania.

The main principles of the executive chain of command over the national defence establishment comply with the requirements of the civil control: only a civilian may be appointed the Minister of National Defence as the main person guiding the implementation of the defence policy; the Ministry itself is partly staffed by civilians and the Defence Staff is subordinated to the Ministry. However, further "civilianisation" of the Ministry must be carried out and better coordination of the activities of the Defence Staff by the Ministry must be achieved.

The Parliament (Seimas) with some delays has passed all the main documents establishing and regulating activities of the National Defence System and the Armed Forces, including the Law on the Basics of National Security and the National Secu- 
rity Strategy. The latter, however, given its crucial importance in establishing national security guidelines, did not receive due hearings in the Parliament before its approval. Certain ill-designed legal provisions or ill-defined implementation thereof, pose some obstacles to efficient democratic control over the National Defence System.

The Parliament also faces some objective difficulties in carrying out efficient oversight over the activities of both: institutions implementing the national security and defence policy and the Lithuanian Armed Forces. First and foremost these difficulties are attributable to the lack of relevant civilian expertise on military matters in the national Parliament. Shortage of civilian expertise in its turn triggers other problems: lack of transparency in the procurement of weapons and ever-feasible corruption; a relative autonomy of the national defence establishment on the matters such as the structure of the Armed Forces etc. The democratic oversight and control over the activities of other armed structures, especially intelligence services, does not receive due consideration among the leading decision makers and parliamentarians and, therefore, may pose some difficulties to the democratic political process of the country in the future.

Mass media, despite of chasing sensational news and the lack of professional expertise in military affairs, is favorable in regard to Lithuanian military. NGOs are also playing an increasingly important role in civil-military relations. Not least, social events organised by the LAF also contribute to a comparatively high (over $40 \%$ ) public support of the LAF. But it is necessary to bear in mind that this support has never been tested by real crises and on a real battlefield in defence of the Homeland. Undesirable as it is, feasibility of the scenario, reminiscent of the events in 1940, always raises doubts (reasonable or not is another subject) within the society about the credibility and readiness of the LAF to defend it.

Not-

withstanding all the remaining shortcomings of the democratic control over the armed structures, the overall situation of civil-military relations and the role of the Armed Forces within the society are as positive as never before in the modern history of Lithuania. 